\title{
Article \\ The Use of Geothermal Energy for Heating Buildings as an Option for Sustainable Urban Development in Slovakia
}

\author{
Andrea Senova *(D), Erika Skvarekova D, Gabriel Wittenberger and Jana Rybarova
}

check for

updates

Citation: Senova, A.; Skvarekova, E.; Wittenberger, G.; Rybarova, J. The Use of Geothermal Energy for Heating Buildings as an Option for Sustainable Urban Development in Slovakia. Processes 2022, 10, 289 https://doi.org/10.3390/pr10020289 Academic Editors: Sergey Zhironkin, Radim Rybar and Kody Powell

Received: 16 December 2021

Accepted: 28 January 2022

Published: 31 January 2022

Publisher's Note: MDPI stays neutral with regard to jurisdictional claims in published maps and institutional affiliations.

Copyright: (C) 2022 by the authors. Licensee MDPI, Basel, Switzerland. This article is an open access article distributed under the terms and conditions of the Creative Commons Attribution (CC BY) license (https:// creativecommons.org/licenses/by/ $4.0 /)$.
Faculty of Mining, Ecology, Process Control and Geotechnologies, Institute of Earth's Resources, Technical University of Kosice, Park Komenskeho 19, 04001 Kosice, Slovakia; erika.skvarekova@tuke.sk (E.S.); gabriel.wittenberger@tuke.sk (G.W.); jana.rybarova@tuke.sk (J.R.)

* Correspondence: andrea.senova@tuke.sk; Tel.: +421-55-6022985

\begin{abstract}
The use of geothermal energy (GE) and the green economy in the environment of Slovak municipalities and towns is significant, due to the reduction in the negative influences and impacts of human society's constant consumer lifestyle. The authors highlight the use of modern scientific knowledge, practical experience, and ever-improving technologies in the field of renewable energy sources RES. The aim of this contribution is to draw attention to the under-utilization of GE's potential in Slovakia. Given the country's commitment to meeting emission limits under EU carbon neutrality agreements by 2050, the use of this resource is very pertinent. Slovakia has significant geothermal resources that are not currently sufficiently utilized. The article suggests using GE to heat housing units of the housing estate near the geothermal source. Three scenarios $\left(60^{\circ} \mathrm{C}\right.$ (pessimistic), $65^{\circ} \mathrm{C}$ (conservative), and $70^{\circ} \mathrm{C}$ (optimistic)) were considered in our energy balance and economic advantage calculations. The green economy offers a sustainable way of using the earth's resources The financial calculations regarding the amount of investment, the expected financial return and the possible values of the saved emissions confirm the possibility of the further use of GE technology. The information under consideration can be used in other significant territories, which may be a theme for further research in this field.
\end{abstract}

Keywords: geothermal energy; renewable technology; thermal energy; investment

\section{Introduction}

The necessity of achieving net zero global $\mathrm{CO}_{2}$ emissions by 2050, to achieve the target set in the Paris Agreement, has stimulated interest in the use of low-carbon energy technologies, including geothermal energy. The constant exploitation of natural resources, excessive waste generation, the emission of harmful substances into the atmosphere (COx, $\mathrm{SOx}, \mathrm{NOx}$, etc.), seas, oceans, and soils lead to negative and often permanent changes. Climate change is manifested by an increase in average temperatures, changes in the nature of the climate, more frequent occurrences of extreme weather (melting of glaciers and permafrost, landslides, extreme drought and heatwaves, torrential rains, sudden flooding, and others). There are changes in biodiversity, the migration of animal species, extinction, excessive deforestation, changing soil composition, and the contamination of water resources (increasing the acidity of the oceans). Population migration is another important manifestation of these changes [1]. However, despite various climate agreements, $\mathrm{CO}_{2}$ emissions reached an all-time high of 35 billion tons per year in 2019. The unprecedented nationwide COVID-19 crisis that began in China at the end of 2019 has rapidly frozen emissions growth. All these reasons, among others, have led to increased interest in the research and development of sustainable and renewable energy (RES) technologies.

Man, through his anthropogenic activity, significantly influences conditions on the planet. At present, the greatest emissions are generated by the burning of coal; for instance, more than 14 billion tons were burned in 2018. Emissions from this source totaled more 
than 12 billion tons in 2018. This ranking is followed by natural gas and its increasing consumption level of almost 8 billion tons, as well as cement production. The EU is the world's largest importer of energy, relying on imports for $50 \%$ of its energy needs. With an energy demand forecast to grow $1-2 \%$ a year, this figure will rise, within the coming 20-30 years, up to 70\%. Europe's energy needs are growing relatively fast compared to other parts of the world. Climate change has encouraged the inclusion of modern RES technologies in the program, to mitigate the negative impacts of fossil fuel energy production. Europe is being forced to invest in new technologies [2,3]. The overall EU average of RES production in 2019 was $20 \%$, meeting its target for 2020 . Iceland has the largest share of RES energy at almost $80 \%$, thus meeting the target above the set limit. This was mainly helped by the geographical relief and nature of the landscape and the wide use of energy from geothermal and water sources-geothermal power plants and hydroelectric power plants. Norway meets about $73 \%$ of its energy needs from RES especially due to the hydroelectric power plants made possible by the mountainous profile of the landscape, offering a bountiful supply of rivers with a high falling gradient. Of the other EU countries, Sweden's share is almost 60\%, Finland's, about 43\%, and Latvia's, 40\%, followed by Denmark, Austria, etc. Included in the leading countries that have not (yet) met their commitments is Slovenia, which produced more than $20 \%$ of its energy from RES in 2019, but the target for 2020 is $25 \%$. Other such countries are Ireland, Belgium, the Netherlands, Luxembourg, the United Kingdom, and Poland. Poland relies mainly on coal production and, therefore, has long had a problem with air pollution. In 2019, Slovakia produced almost $20 \%$ of its total energy from RES, thus meeting its 2020 target [4].

Geothermal energy, as a renewable energy source, can be an important resource for numerous regions of Europe. The development of geothermal energy facilities gives people the potential to gain better control of their own local energy resources and take advantage of a secure, environmentally friendly and domestic source of energy. This energy from within the Earth can be used for different purposes to improve environmental quality and protect public health and safety. The technological and sustainable development of this type of energy will help to solve the world's energy needs and the requisite challenges [5]. For geothermal electricity production, the highest concentration of resources on the European continent is located in Italy, Iceland and Turkey; the present exploited value is only $0.3 \%$ of the whole renewable market. The possibilities for geothermal energy to expand its penetration in Europe are mainly from using the enhanced geothermal system (EGS). Some areas have been critically investigated regarding geothermal resource base assessment, recoverable EGS estimates, in-depth research on EGS technologies and the current performance, the designing of suburb-facing systems, drilling technology economics, the conversion of energy using enhanced geothermal systems, the effect of this technology on the environment, and the analysis of enhanced geothermal systems and their sustainability [6,7].

Slovakia should take advantage of the potential geothermal resources it has, which are currently used to a minimal extent. It is important to use energy resources efficiently because the price of energy, in general, is rising [8].

Is geothermal energy renewable? Geothermal energy has often been described as a renewable energy resource. However, on the time scale normally used in human society, geothermal resources are not, strictly speaking, renewable. They are renewable only if the heat extraction rate does not exceed the reservoir replenishment rate. Exploitation through wells, sometimes using down-hole pumps in the case of non-electrical uses, leads to the extraction of very large quantities of fluid, and consequently to a reduction or depletion of the geothermal resources that are in place [9]. Geothermal localities can be subdivided into two categories: springs and deep boreholes. Springs are locations where geothermal water naturally flowed out or is still flowing out from the aquifer onto the earth's surface. The category of deep boreholes accounts for all the localities where there are not, nor have there ever been any natural springs, but where geothermal waters have been found during hydrocarbon exploration and exploitation [10,11]. 
The drilling works enable geologists to establish the rock composition of an investigated area, along with other data that are connected to the tasks needed in the eventuality of a geothermal energy plant [12]. Geothermal fields, as opposed to hydrocarbon fields, are generally systems with a continuous circulation of heat and fluid, where fluid enters the reservoir from the recharge zones and leaves through discharge areas (hot springs, wells) [7]. Heat production from GE is widespread in many countries of the world. The largest geothermal central heating systems are in the USA and China; in Europe, it is mainly found in France, Germany, Iceland or Turkey [13]. Slovakia has the greatest potential for GE in Central and Eastern Europe [3].

The aim of this article is to demonstrate how to carry out an analysis of an area examined in terms of the availability of a site suitable for GE domestic heating systems, the availability of distribution networks, and energy needs. We provide a case study of how a GE system can be used from the perspectives of investment efficiency, environmental impact, and meeting user needs. Practical information and advice on procedures can help other cities in terms of future perspectives.

\section{Materials and Methods}

This article addresses the issue of obtaining and using a renewable energy source (RES) for heating purposes, district heating (DH), and domestic hot water (DHW). With this energy-clean technology, it is possible to minimize the production of emission substances and replace the combustion of natural gas during heating.

Data that is publicly available and at the same time processed by us in the case study have been used for the processing of this contribution. The procedures and methods are summarized as follows:

- Based on the available information, we analyzed the possibilities of using geothermal energy in the environment of towns and villages in the area of the High Tatras (Podtatranská basin). To design a model of geothermal energy use for heating, we considered a mining well to serve a housing estate of 5500 households.

- We created a methodology for determining the profitability of a geothermal well using a flow chart. We designed a technology setup for the use of geothermal well energy. The energy potential and energy balance were calculated. The complexity and return on investment were assessed. The volume of emissions of harmful substances that can be saved by using this clean energy was calculated. Based on the findings, we assessed the usability of a geothermal well for the purpose of heating apartments.

\subsection{Hydrogeological and Hydrogeothermal Conditions in Slovakia}

Due to its natural conditions, the Slovak Republic has significant potential geothermal energy. Based on research and surveys to date, the energy potential of GE is important in Slovakia, and its value is at $5538 \mathrm{MWt}$. Geothermal energy sources are mainly represented by geothermal waters, which are tied to hydrogeological collectors located at depths of 200-5000 m. In Slovakia, the average temperature increase is $3-3.8^{\circ} \mathrm{C}$ for every $100 \mathrm{~m}$ of the borehole; at a depth of $3 \mathrm{~km}$, the temperature is about $100{ }^{\circ} \mathrm{C}$. Geothermal sources are divided according to temperature $\left({ }^{\circ} \mathrm{C}\right)$, into:

- Low temperature-from $20^{\circ} \mathrm{C}$ to $100{ }^{\circ} \mathrm{C}$ : these are geothermal sources with a moderate temperature, suitable only for heating and recreational purposes;

- Medium temperature-from $100{ }^{\circ} \mathrm{C}$ to $150{ }^{\circ} \mathrm{C}$ : these are suitable for heating and using binary cycles, and for electricity generation;

- High temperature-above $150{ }^{\circ} \mathrm{C}$ : these are geothermal sources suitable for electricity generation (using water vapor).

In terms of well yield, geothermal sources are distinguished as follows:

- With minimum yield - up to $1.0 \mathrm{~L} \cdot \mathrm{s}^{-1}$;

- With very little yield- from 1.0 to $5.0 \mathrm{~L} \cdot \mathrm{s}^{-1}$;

- With a small yield-from 5.0 to $10.0 \mathrm{~L} \cdot \mathrm{s}^{-1}$; 
- With medium yield- from 10.0 to $25.0 \mathrm{~L} \cdot \mathrm{s}^{-1}$;

- With great yield—from 25.0 to $50.0 \mathrm{~L} \cdot \mathrm{s}^{-1}$;

- With very high yield—above $50.0 \mathrm{~L} \cdot \mathrm{s}^{-1}[14]$.

The wells that have been carried out so far (at depths of 92-3616 m) have verified temperatures at the wellhead of $18-129^{\circ} \mathrm{C}$. The yield of free-range wells ranged from tenths of a liter to $100 \mathrm{~L} \cdot \mathrm{s}^{-1}$, with a predominantly $\mathrm{Na}-\mathrm{HCO}_{3}-\mathrm{Cl}, \mathrm{Ca}-\mathrm{Mg}-\mathrm{HCO}_{3}$ and $\mathrm{Na}-\mathrm{Cl}$ water type, with mineralization of $0.4-90 \mathrm{~g} \cdot \mathrm{L}^{-1}$ [15].

Slovakia, considering its small surface area $\left(49,000 \mathrm{~km}^{2}\right)$, is very rich in mineral and thermal waters. There are 1200 springs registered on its territory, the equivalent of one spring for every $40 \mathrm{~km}^{2}$. The rich physicochemical diversity of waters and their even spread throughout the territory is conditioned by the favorable geological-tectonic construction of the territory and its geothermal activity.

From north to south, mineral and thermal waters are linked to sediments of the Flysch zone and the Klippen belt of the Paleogenic and Mesozoic eras, the crystalline rocks of the Paleozoic and Mesozoic, the dolomites and limes of the Mesozoic, and Flysch sediments of Inner Carpathian Paleogene and Neogene origin. The temperature of the waters of the springs is between 15 and $70{ }^{\circ} \mathrm{C}$. Mining works carried out in some areas obtained water with temperatures in the range of $40-130{ }^{\circ} \mathrm{C}$. The yield of natural springs varies between 1 and $40 \mathrm{~L} \cdot \mathrm{s}^{-1}$. The well yield is from 5 to $90 \mathrm{~L} \cdot \mathrm{s}^{-1}[16,17]$. From the point of view of geothermal water sources, we can only consider as a possibility the Paleogene subsoil in the area of interest, which consists mainly of Triassic carbonates of Krížna Nappe and Choč Nappe, with Karst-fissure permeability. Overall, the geothermal activity of the area of interest can be assessed in terms of the density of the earth's heat flow as average geothermal output $\left(65-70 \mathrm{~mW} \cdot \mathrm{m}^{-2}\right)$. Temperatures at the depth of storage of the collectors (1400-3000 m below the surface) are about $45-95^{\circ} \mathrm{C}$. Mineral waters reflect the hydrogeological, hydrological, geological, and structural conditions in the monitored area. The nature of the waters indicates that Triassic structures correlate well with the appearance of Triassic carbonate rocks on the surface around the basin. The nature of the waters in the Paleogene subsoil may have been obviously marine in origin, i.e., waters that have been preserved after the transgression of the Paleogene Sea but are now more or less infiltrated surface waters from the peripheral parts of the basin. The total mineralization of the waters in the Mesozoic subsoil, based on the results of the pumping tests in the surrounding wells, can be expected in the range of $3-5 \mathrm{~g} \cdot \mathrm{L}^{-1}$. Information on the hydrogeological conditions of the territory comes mainly from the quaternary sediments of Poprad, where several exploration wells were created. Several deeper wells were created in the Poprad Basin, the results of which provided valuable data on groundwater properties in individual geological units. From this point of view, valuable information can be drawn from the wells in the areas of Stará Lesná (FGP-1), Poprad (PP-1) and Vrbov (VR-1, 2, 2A, 3) and the latest from the area of Vel'ká Lomnica. Since the PP-1 borehole (Poprad) is relatively close to the site under examination, its results may be analogous to those of the projected well. At the PP-1 well in Poprad, the geothermal waters, of a significantly calcium-magnesium-sulfatesulphate-hydrogen carbonate type, were verified as having an average mineralization value of $2.88 \mathrm{~g} \cdot \mathrm{L}^{-1}$, with a $\mathrm{pH}$ value of 6.21 . The water is over-gassed with $\mathrm{CO}_{2}$. The increased sulfuret content is due to the dissolution of plaster stone and anhydrite. The incidence of sodium is low because it is released due to the low $\mathrm{pH}$ [18].

Groundwater resources and reserves in Slovakia vary not only depending on the location and time but also in terms of their quality. Although they are regularly renewed, they are not unlimited and only proper use can ensure their relative inexhaustibility. Groundwater, which is a source of quality drinking water, is the most important natural wealth in Slovakia. Therefore, the most fundamental task is getting to know the laws of groundwater creation and flow as well as its protection. This requires very close monitoring, documenting and registering their basic characteristics and parameters. The total usable amounts of groundwater in Slovakia, as documented in 2018 in all categories, represent $77,175.07 \mathrm{~L} \cdot \mathrm{s}^{-1}$. 
Those usable quantities also include usable amounts of thermal water as an integral part of groundwater and, for the sake of completeness, part of the mineral waters, in particular the usable quantities of mineral waters approved by the Hydrogeological Commission [19]. Figure 1 shows the prospective areas of geothermal waters in the Territory of the Slovak Republic.

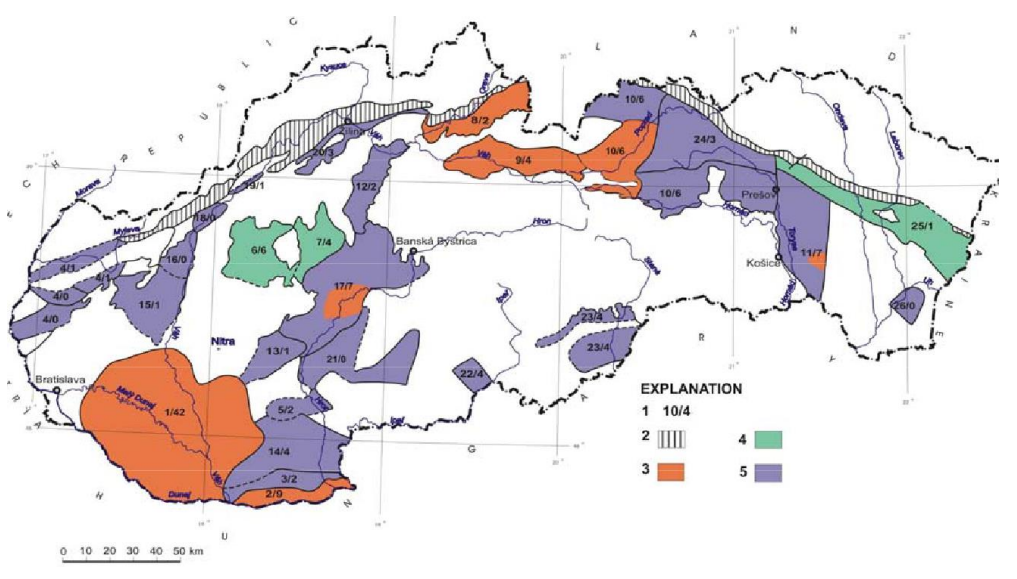

Figure 1. Prospective areas of geothermal waters in Slovakia [19]. (1) 10/4; (2) Klippen belt; (3) prospective areas where hydrogeothermal evaluation has been carried out; (4) prospective areas where hydrogeothermal evaluation is being carried out; (5) prospective areas where hydrogeothermal evaluation has not yet been carried out.

In order to create the best possible conditions for the use of geothermal energy, regional hydrogeothermal evaluations are carried out by determining the quantity of geothermal waters and geothermal energy in the defined 27 hydrothermal areas or structures of Slovakia [20]. Current geothermal conditions in Slovakia are mapped out and reviewed in detail. There are currently 27 prospective geothermal areas that have been defined (Figures 1 and 2).

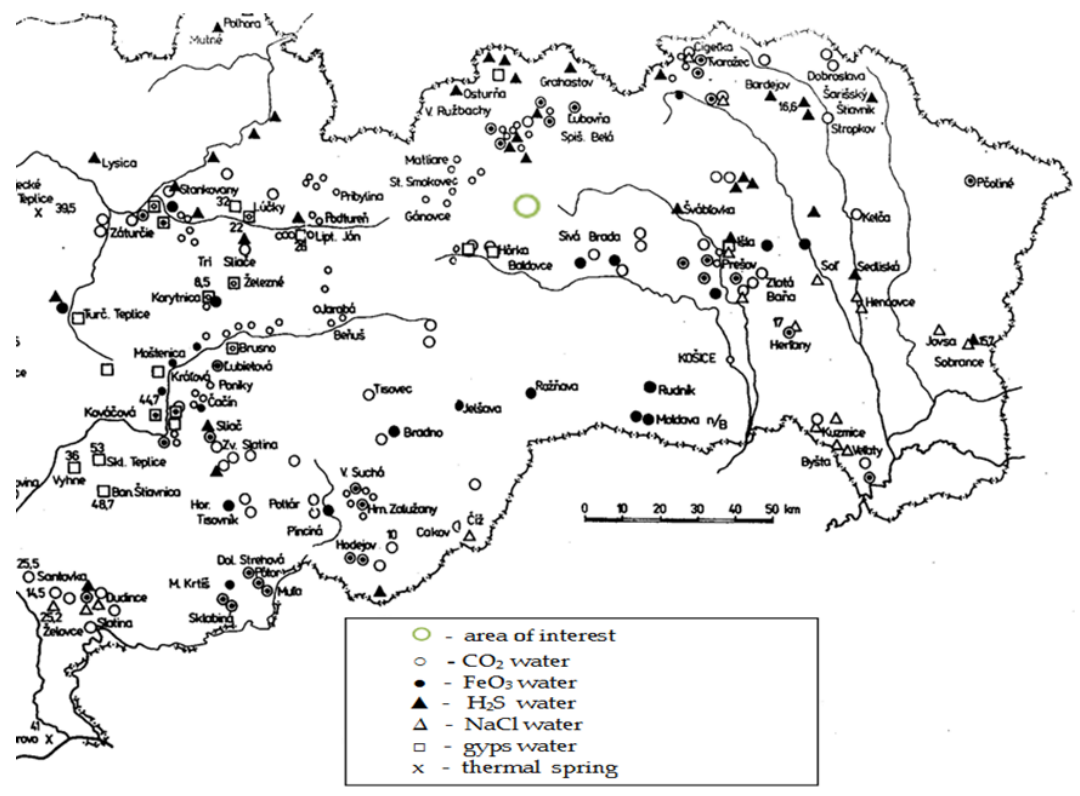

Figure 2. Partial map of geothermal wells in Slovakia.

A large proportion of geothermal reservoirs provide water with a temperature of up to $135^{\circ} \mathrm{C}$, which is optimal for use for heating buildings or for recreational purposes. 
Geothermal energy (GE) is not primarily used for efficient electricity generation. Modern technologies also make it possible to generate electricity using a binary cycle [13].

\subsection{Technological Description of Geothermal Well Utilization}

The proposed geothermal well is GTK-1 Kežmarok, with an estimated depth of 2800 m; the relevant technological and piping equipment for the purpose of using geothermal energy for $\mathrm{DH}$ production and the preparation of DHW in existing block boiler rooms on the housing estate. Currently, housing estate boiler rooms are used for the supply of DH and DHW to apartment buildings, civic facilities, and other buildings in the city. Thermally treated geothermal water will be discharged into a nearby surface flow system. The physicochemical properties of geothermal water and its impact on the material of the pipes are also fully taken into account. Geothermal energy is expected to be used in an open system, with the newly proposed GTK-1 geothermal well serving as a drilling (pumping) well.

The exploitation of geothermal water by free flow has been considered, with water from the well estuary (mouth) entering the separation and storage vessel, where it will be relieved of free gases. Consequently, it will be pumped (if there is not enough pressure at the mouth of the well) and overdrawn in the ground to the isolated pipelines, then carried to an heat exchanger station situated close to the well. In the heat exchanger station, geothermal water transmits its heat to the secondary treated heating system water, by which method geothermal heat will be distributed in a closed and hydraulically separated circuit to 3 boiler rooms, in a ground-stored isolated pipe. Heat exchangers will be added in existing boiler rooms to heat the returning heating water and the preheat/heating of the DHW. After thermal use, geothermal water from the heat exchanger station will be transported under the ground by stored pipes without thermal insulation to a nearby surface stream (see Figure 3).

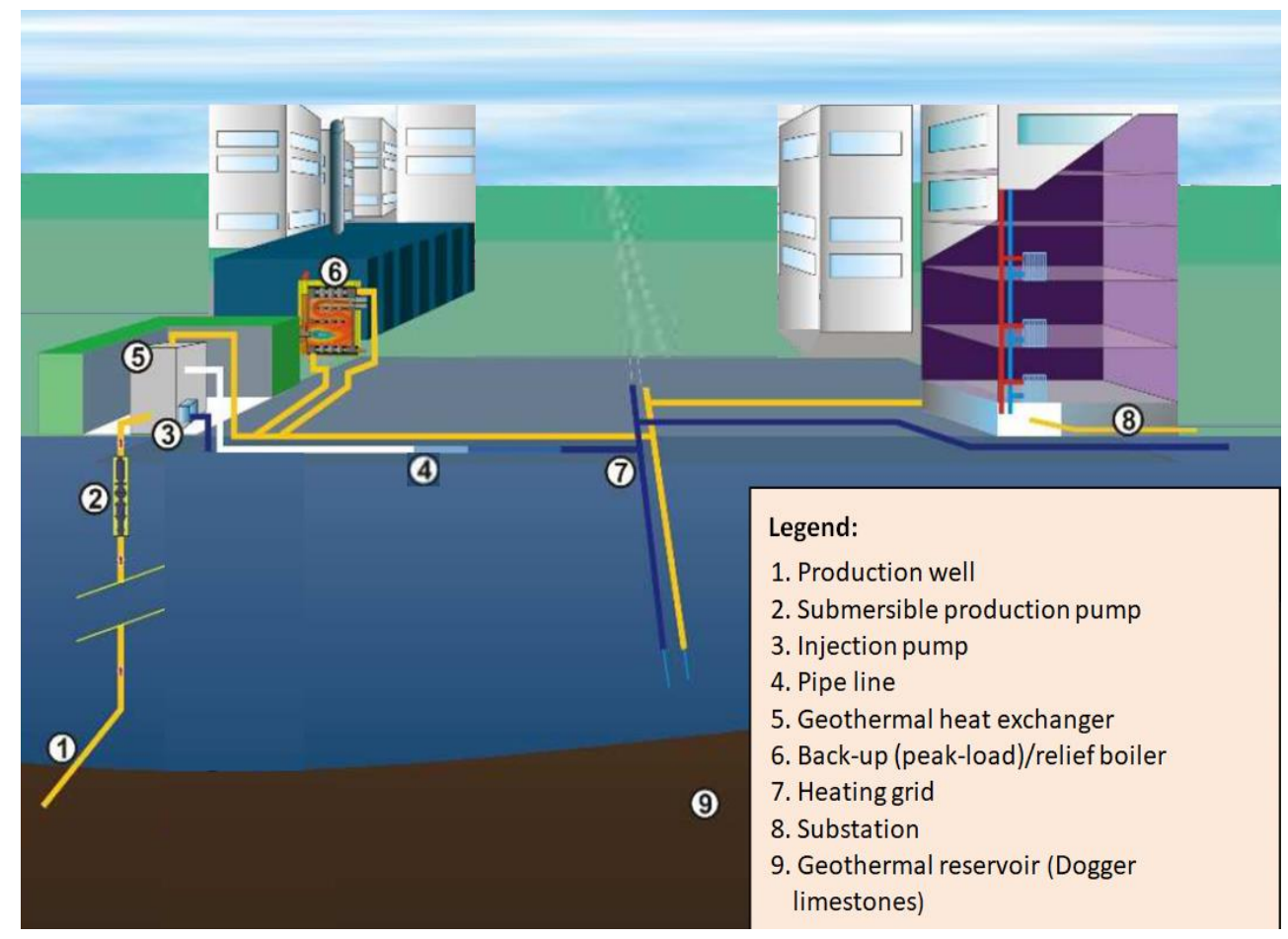

Figure 3. Scheme of district heating using geothermal energy. 
2.3. Methodology for Determining the Suitability of Geothermal Well Usage in the Monitored Area (Podtatranska Basin)

Hydrogeologically, the projected well is situated in explored territory in the Poprad River Basin. It has a left-hand tributary from the High Tatras and the right-hand tributary is mainly from the Levoča Hills. Water management is important in the area since the surface waters of the tributary of Poprad and the groundwater from its alluvia are often used for drinking water supply. Water quality in the river is influenced by industrial enterprises and local agglomerations. The area of the Sub-Tatran Basin under investigation offers the use of several types of RES in different locations of the territory, in order to reduce negative environmental impacts, especially in terms of reducing emissions or replacing the combustion of fossil fuels. Fossil fuel heating is one of the largest sources of $\mathrm{CO}_{2}$ emissions. The best solution is the use of thermal energy from geothermal sources.

Geothermal energy is an available local, strong energy source that is characterized by stability of supply, regardless of current climatic conditions. Geothermal energy is a long-term and sustainable energy source. Based on the geological construction of the surrounding area and the conditions of geothermal wells that have already been realized, it is possible to expect a well yield in the range of $20-30 \mathrm{~L} \cdot \mathrm{s}^{-1}$, with a total mineralization of about $3-5 \mathrm{~g} \cdot \mathrm{L}^{-1}$ and a water temperature at the surface of $60-70{ }^{\circ} \mathrm{C}$. One definite point of uncertainty, according to the study, may be the depth of the collectors; therefore, the study recommends counting on the final mining depth being $2800 \mathrm{~m}$ [21].

Based on analyses of the available data, we assume that there is potential for the practical use of GE in the monitored Podtatranska Basin. GE may replace the combustion of natural gas in the supply of housing units under the current model. This creates ideal conditions for:

- Limiting the use of energy derived from fossil and conventional fuels;

- $\quad$ Reducing $\mathrm{CO}_{2}$ emissions, (NOx, $\left.\mathrm{CO}, \mathrm{SO}_{2}, \mathrm{TZL}\right)$

- Stabilizing heat prices,

- Obtaining a stable, green, and renewable energy source.

The aim of the methodological procedure (Figure 4) is to choose the appropriate technology to cover the energy needs of the chosen location-a housing estate-based on sustainability, local availability, and affordability, and with a positive impact on the environment, as an exemplary model of energy independence for towns and villages.

The methodology begins with the search for theoretical knowledge in the field of RES energy. This draws attention to the call for a transition to renewable and sustainable energy sources within the European Union, which aims to achieve carbon neutrality by 2050 .

Following a subsequent evaluation and the selection of appropriate information, the individual available RES technologies were evaluated for:

- The area of energy coverage of household needs;

- The types and principle of operation; and

- A large-scale and stable supply for the population throughout the year.

From the information found, geothermal energy appears to be the most suitable form of energy. With the subsequent selection of the site and the examination of existing technologies covering the energy needs of the housing estate, it is possible to proceed with an evaluation of the most appropriate RES technology. Our research has shown that the technology used has the best potential and the appropriateness of the subsequent investment is confirmed by further calculation. 


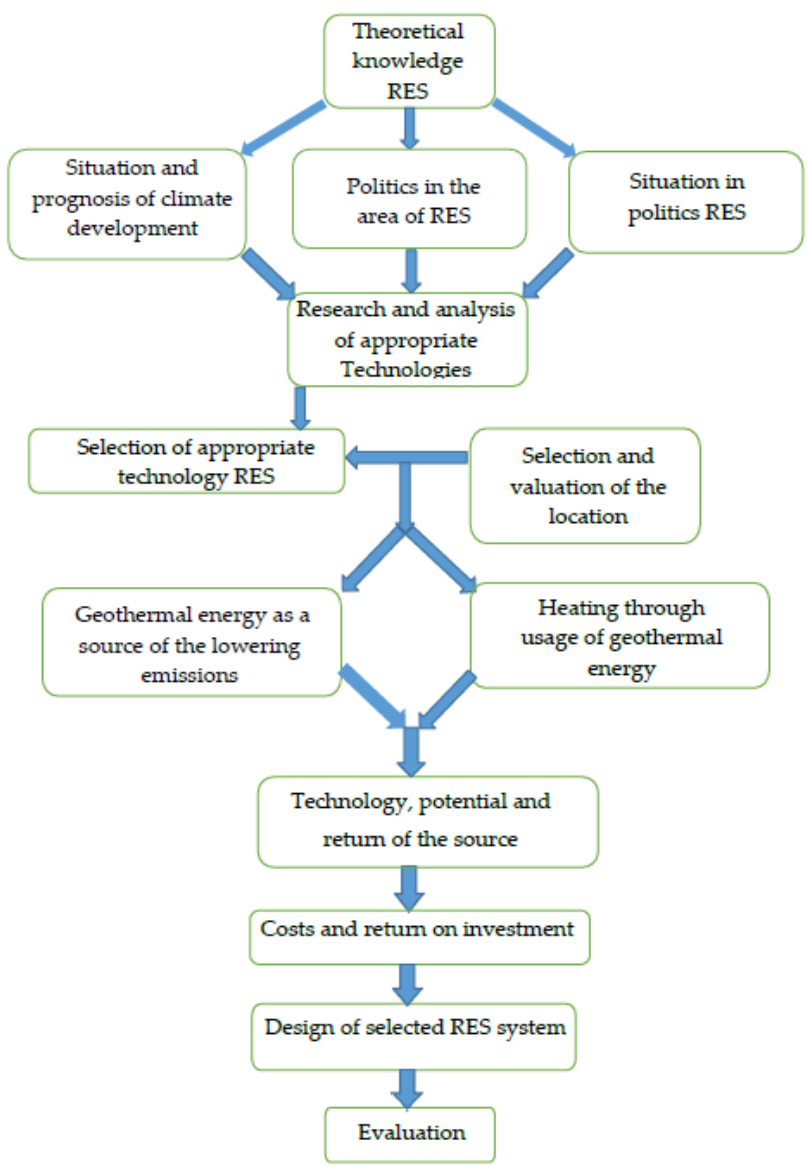

Figure 4. Flowchart methodology for the work of detecting a suitable GE source.

The processing of the geothermal contribution was based on data from the technical study of the geothermal well GTK-1, which is publicly available [21]. A specific site (GTK-1, Figure 5) has been designated in which to carry out the geothermal well under investigation. Residential houses (in a housing estate with a population of 5500) were selected that met the requirements for the use of geothermal energy from the borehole. To determine the yield of a geothermal source for heating the estimated capacity needed for the source was compared with the heating volume of 3 boiler rooms in previous years (average of years 2015-2017).

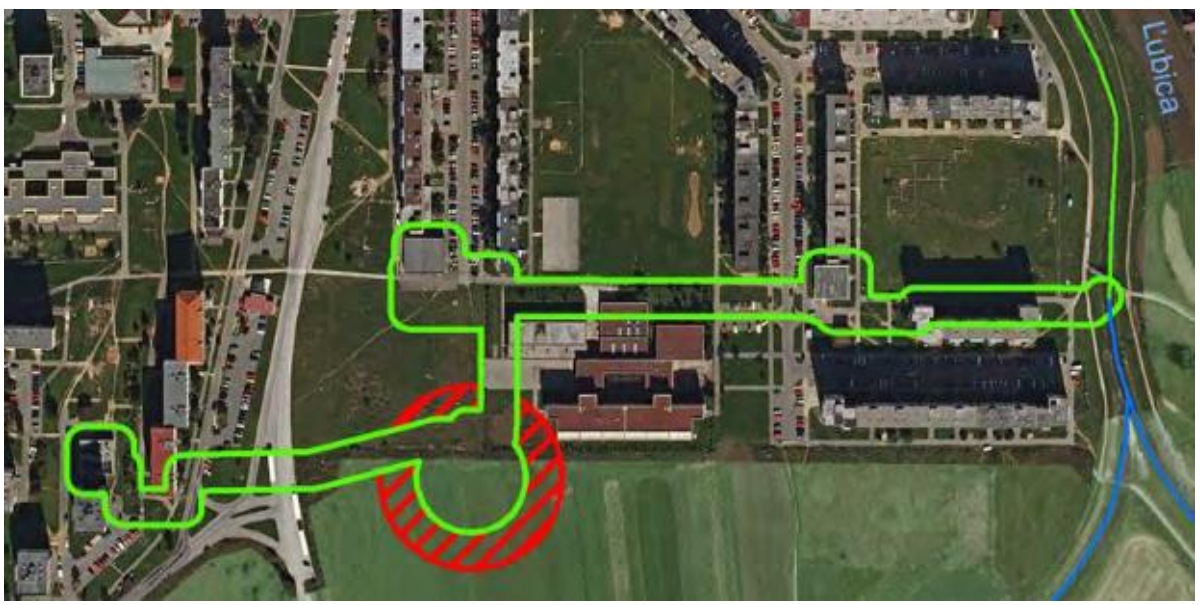

Figure 5. Location of the proposed GTK-1 well area under investigation [21]. 
The calculation of the energy potential of the geothermal source was based on the following parameters: yield, mineralization, and water temperature at the surface. Given that it is not possible to determine the exact temperature of geothermal water on the basis of current knowledge, three variants of geothermal water temperature $\left(60^{\circ} \mathrm{C}, 65^{\circ} \mathrm{C}\right.$ and $70{ }^{\circ} \mathrm{C}$ ) have been considered when calculating the energy potential.

\subsection{Procedure for Calculating the Chosen Technology's Potential Using Geothermal Energy}

A methodological procedure was used to evaluate the use of the suggested possibilities regarding suitable RES technology with the best potential and lowest subsequent investment, with a recalculation, determination, and proposal as to whether the given system (investment) is suitable. The procedure for calculating the investment technology chosen, using geothermal energy, is as follows:

- Calculation of the Return on Investment (ROI)

ROI is the most frequently used parameter for the assessment of the economic efficiency of investments. It is the total income that results from concrete investments, divided by the amount of investment funds. This indicator is completely time-independent [22].

$$
\text { Return on Investment ROI }=\frac{\text { cumulative incomes }}{\text { total investments }}
$$

\section{- $\quad$ Calculation of Cash Flow (CF)}

Calculation of the annual cash flow is carried out on the basis of the following relationship [22]:

$$
\mathrm{CF}=\text { incomes investments }- \text { production costs }
$$

$\mathrm{CF}$, or annual cash flow (annual income), is the product of the unit price of natural gas (EUR 0.0219/kWh, for 2021) and the amount of heat produced (DH and DHW) in kWh (MWh) with a difference in estimated annual operating costs (EUR).

The cash flow of a project is the sum of positive and negative items, incomes and costs, connected with a certain activity. The sum of all financial flows, which results from the investment into a project, is called the cash flow produced by capitalized investments.

- $\quad$ Calculation of Net Present Value (NPV)

$$
\mathrm{NPV}=\sum_{\mathrm{i}=1}^{\mathrm{n}}\left\{\left(-\mathrm{I}+\mathrm{CF}_{\mathrm{i}}\right) /(1+\mathrm{a})^{\mathrm{i}}\right\}
$$

where:

NPV—net present value;

I-investments;

CF-cash-flow;

a-update rate;

i-current year;

$\mathrm{n}$-project duration.

If the NPV of the first project is higher than the NPV of the second project, and vice versa-the ROI of the first project is smaller than the ROI of the second project (NPV1 > NPV2; ROI1 < ROI2). In this case, there is no precise mathematical formula defining which of the two projects is better. The volume of investments and the risk level of the project will probably play the most important role. The intuition and experience of the project evaluator, as well as other arguments, can influence investment decisions.

- $\quad$ Calculation of Payback Period (pBp)

A payback period is the project's duration, from its beginning until the point when the cumulative cash flow becomes positive. Although in the case of some projects, the assessment results based on the payback period may seem interesting, this indicator does 
not say anything about the project's future course from the viewpoint of its cash-flow development. This could be either positive or negative.

- Calculation of Emission Values for Natural Gas Heating

The $\mathrm{CO}_{2}$ emission factors needed to calculate $\mathrm{CO}_{2}$ emissions from the operation of buildings (heating, hot water preparation and the operation of other appliances) are country-specific or operational (and also different for each IPCC1 category) and are derived from specific fuel characteristics. Average $\mathrm{CO}_{2}$ emission factors are used for natural gas, hard coal, lignite by region of origin (Slovak, Ukrainian and Czech), and coke. Due to these reasons, emission factors should be revised each year $[23,24]$.

The values of the weighted arithmetic mean of the qualitative parameters of natural gas, distributed in the territory of the Slovak Republic by SPP—distribúcia, a.s, were used according to the method followed in [25]. Density, calorific value, combustion heat and Wobbe number are given for the business unit, i.e., $\mathrm{m}^{3}$ at $15^{\circ} \mathrm{C}$, pressure $0.101325 \mathrm{MPa}$, and relative humidity $\varphi=0$. The formula used for the conversion of units: $1 \mathrm{kWh}=3.6 \mathrm{MJ}$.

Annual consumption of MNG NG at a calorific value of $34,848 \mathrm{MJ} / \mathrm{m}^{3}$ [26]:

$$
\mathrm{M}_{\mathrm{NG}}=\frac{\text { annual heat consumption }}{\text { calorific value } \cdot \text { boiler efficiency }}
$$

\section{- Calculation of Energy Potential}

The energy potential is an elementary indicator of the possibility of using geothermal water. The energy potential of water, which is heated by the action of the earth's core, is its heat output [27].

$$
\mathrm{P}_{\mathrm{t}}=\mathrm{m} \cdot \mathrm{c}_{\mathrm{v}} \cdot \Delta \mathrm{t}
$$

where:

$\mathrm{Pt}$-thermal power $(\mathrm{kW})$

$\mathrm{m}$-weight $\left(\mathrm{kg} \cdot \mathrm{s}^{-1}\right)$

$\mathrm{c}_{\mathrm{V}}$-specific water heat $\left(\mathrm{m}^{-3} \cdot \mathrm{K}^{-1}\right)$

$\Delta \mathrm{t}$-temperature difference $(\mathrm{K})$

- Determination of the Energy Balance

Three variants of geothermal water temperature $\left(60^{\circ} \mathrm{C}, 65^{\circ} \mathrm{C}\right.$ and $\left.70{ }^{\circ} \mathrm{C}\right)$ were considered when determining the energy balance. Natural gas savings were assessed by comparing the average natural gas consumption for 2015-2017 and the energy balance of geothermal energy as a percentage; thus, it was also possible to assume an approximate reduction in $\mathrm{CO}_{2}$ production.

When processing the energy balance of the GTK-1 geothermal source, we will take into account the following assumptions:

- Geothermal energy will be used for heating the housing estate of the DH and for the preparation of DHW.

- Heat loss or a temperature drop of $4 \mathrm{~K}$ due to the use of heat exchangers is considered.

- The daily operating time of boiler rooms is assumed to be $16 \mathrm{~h}$.

- A maximum heating water temperature of $70^{\circ} \mathrm{C}$ is assumed.

- A reduction factor in the use of geothermal energy for each whole $1{ }^{\circ} \mathrm{C}$ rise in the external temperature, which takes into account differences in outdoor temperatures during the day and resulting fluctuations in the temperature of the heating water. The reduction factor varies for different geothermal water temperatures.

- Thermally used geothermal water will be discharged into a nearby stream.

The energy balance will be processed for individual scenarios: the pessimistic scenario (geothermal water temperature of $60^{\circ} \mathrm{C}$ ), the conservative scenario (geothermal water temperature of $65^{\circ} \mathrm{C}$ ) and the optimistic scenario (geothermal water temperature of $70{ }^{\circ} \mathrm{C}$ ). To process the energy balance, it is necessary to know the following values: 
- $\quad$ Number of days of temperature duration from $13^{\circ} \mathrm{C}$ to $-16^{\circ} \mathrm{C}$;

- Temperature of the supply and return heating water;

- Average heat output per DH;

- Amount of heat produced per DH;

- Amount of heat produced per DHW;

- Usable thermal output of the geothermal source for DH;

- $\quad$ Reduction factor for the use of geothermal energy for $\mathrm{DH}$.

\section{Results and Discussion}

In the context of rising energy (heat/electricity) prices and societal pressure on environmental impacts in terms of the green economy, the interest of business owners/population/society in ecological sources of energy production (heat/electricity) is increasing. The design of a GE system for heating towns and villages is problematic, due to several of the input parameters of the calculation. The timing mismatch, the suitability of site selection in terms of the time optimization of production, the capacity of the distribution network, daily consumption, and the possibility of using GE as an energy source for building heating systems are data that has to be mutually optimized when dimensioning a balanced energy system.

\subsection{Determination of the Parameters of the Proposed Geothermal Well}

The predicted physicochemical properties of geothermal water from the proposed GTK-1 borehole are similar to geothermal boreholes already created in the vicinity of the Podtatranska Basin (wells Vr-1 and Vr-2 Vrbov, VL-1 Vel'ká Lomnica).

The mineralization type of $\mathrm{Ca}-\mathrm{Na}-\mathrm{HCO}_{3}-\mathrm{SO}_{4}$ is assumed, i.e., a composition similar to Vrbov; the dominant cationic components will be calcium (up to $600 \mathrm{mg} \cdot \mathrm{L}^{-1}$ ), sodium (up to $300 \mathrm{mg} \cdot \mathrm{L}^{-1}$ ) and magnesium (about $150 \mathrm{mg} \cdot \mathrm{L}^{-1}$ ), with anionic components of bicarbonate concentrations (about $2000 \mathrm{mg} \cdot \mathrm{L}^{-1}$ ) and sulfites (up to $700 \mathrm{mg} \cdot \mathrm{L}^{-1}$ ). Total mineralization is estimated to be up to $3 \mathrm{~g} \cdot \mathrm{L}^{-1}$. The concentration of strontium (approx. 10 $\mathrm{mg} \cdot \mathrm{L}^{-1}$ ) and potassium (80 to $100 \mathrm{mg} \cdot \mathrm{L}^{-1}$ ) will also be increased. Radioactivity will also be slightly increased compared to the natural background. Trace amounts of sulfide can also be expected. The expected phase ratio (dissolved gas content) will be up to $1 \mathrm{~m}^{3} \cdot \mathrm{m}^{-3}$ of geothermal water, the main component being carbon dioxide ( 95 to $98 \%$ by volume), the remainder is mainly nitrogen and methane, with a small admixture of ethane, propane, isobutene, etc. [22].

Table 1 shows the predicted parameters of the geothermal borehole in the explored site of the Podtatranska Basin, based on an analogy of geothermal wells located nearby.

Table 1. Predicted parameters of the proposed geothermal well.

\begin{tabular}{cccc}
\hline Scenario & Pessimistic & Conservative & Optimistic \\
\hline Geothermal water temperature at the mouth of the well $\left({ }^{\circ} \mathrm{C}\right)$ & 60 & 65 & 70 \\
Yield geothermal well $\left(\mathrm{L} \cdot \mathrm{s}^{-1}\right)$ & 25 & 25 & 25 \\
Mineralization $\left(\mathrm{g} \cdot \mathrm{L}^{-1}\right)$ & & $3-5 \mathrm{~g} \cdot \mathrm{L}^{-1}$ & 788,400 \\
Usable amount of geothermal water per year $\left(\mathrm{L} \cdot \mathrm{s}^{-1}\right)$ & 788,400 & 5233.8 & 788,400 \\
Theoretically usable energy potential $(\mathrm{kW})$ & 4710.4 & 5757.1 & $50,432.4$ \\
Theoretically usable annual amount of heat $(\mathrm{MWh})$ & $41,262.9$ & $45,847.7$ & \\
\hline
\end{tabular}

Table 2 shows the values of total annual heat production and NG consumption for the years 2015 to 2017 . 
Table 2. Total heat production and consumption of natural gas in the selected location, (source: elaborated by authors).

\begin{tabular}{|c|c|c|c|c|c|c|}
\hline \multirow{3}{*}{$\begin{array}{c}\text { Year } \\
\text { Type of } \\
\text { (MWh) }\end{array}$} & \multicolumn{2}{|c|}{2015} & \multicolumn{2}{|c|}{2016} & \multicolumn{2}{|c|}{2017} \\
\hline & $\mathrm{DH}$ & DHW & $\mathrm{DH}$ & DHW & $\mathrm{DH}$ & DHW \\
\hline & 17,964 & 9565 & 19,084 & 9565 & 18,975 & 9290 \\
\hline Total DH + DHW (MWh) & \multicolumn{2}{|c|}{27,529} & \multicolumn{2}{|c|}{28,649} & \multicolumn{2}{|c|}{28,264} \\
\hline Total consumption (NG) Total DH + DHW (kWh) & \multicolumn{2}{|c|}{$15,021,319$} & \multicolumn{2}{|c|}{$15,558,809$} & \multicolumn{2}{|c|}{$15,474,532$} \\
\hline Total consumption (NG) DH + DHW $\left(\mathrm{m}^{3}\right)$ & \multicolumn{2}{|c|}{$1,398,633$} & \multicolumn{2}{|c|}{$1,448,678$} & \multicolumn{2}{|c|}{$1,440,831$} \\
\hline
\end{tabular}

- Calculation of saved emission values using geothermal energy

Table 3 shows the specific values of individual emission substances that pollute the environment by burning natural gas. The recalculation was carried out according to the literature [23]; these pollutants would be eliminated by using the thermal energy of the geothermal well. The replacement of NG with geothermal energy minimizes the greenhouse effect.

Table 3. Calculation of emissions from natural gas heating.

\begin{tabular}{cc}
\hline Annual Emissions from Natural Gas Heating (kg) \\
\hline TZL & 270.8 \\
$\mathrm{SO}_{2}$ & 32.5 \\
$\mathrm{NOx}$ & 5958 \\
$\mathrm{CO}$ & 1997 \\
$\mathrm{TOC}$ & 253.9 \\
Total emissions $(\mathrm{kg})$ & 8512.2 \\
\hline
\end{tabular}

These pollutants would be eliminated annually for a housing estate with about 5500 residents. The calculation of emissions in NG heating was recalculated according to the literature [23] (see Table 3).

- $\quad$ Energy balance of geothermal well

Geothermal wells offer a number of positive options in terms of reducing negative environmental impacts in the long term. The presumed energy potential of the well could supply the housing estate with hot water intended for heating and hot service water preparation in full coverage, but a certain amount of natural gas usage is still envisaged by heating, to cover possible failures of the energy system.

We considered the following values:

- $\quad$ The specific weight of salt water of $1025 \mathrm{~kg} \cdot \mathrm{m}^{-3}$;

- $\quad$ Specific water heat $\mathrm{c}_{\mathrm{V}}=4.18 \mathrm{MJ} \mathrm{m}^{-3} \mathrm{~K}^{-1}$;

- Temperature difference (for pessimistic, conservative, and optimistic scenarios) $\Delta t=42$, 45 and $55 \mathrm{~K}$.

The energy balance of a geothermal well at 3 different geothermal water temperatures was determined as shown in Table 4.

Table 4. Energy balance of geothermal well GTK-1.

\begin{tabular}{cccc}
\hline Geothermal Water Temperature & $\mathbf{6 0}^{\circ} \mathbf{C}$ & $\mathbf{6 5}^{\circ} \mathbf{C}$ & $\mathbf{7 0}^{\circ} \mathbf{C}$ \\
\hline Annual amount of heat produced for DH (MWh) & 8538.8 & 8538.8 & 8538.8 \\
Annual amount of heat produced for DHW (MWh) & 4676.5 & 4676.5 & 4676.5 \\
Annual production of heat TOTAL (MWh) & $13,215.3$ & $13,215.3$ & $13,215.3$ \\
- geothermal energy (MWh) & 9763.1 & $11,070.3$ & $12,091.4$ \\
- geothermal energy (\%) & 74 & 84 & 91 \\
- natural gas (MWh) & 3452.2 & 2,45 & 1123.9 \\
- natural gas (\%) & 26 & 16 & 9 \\
Annual average efficiency of geothermal energy (\%) & 24 & 24 & 24 \\
\hline
\end{tabular}


The energy potential of geothermal water from the proposed well has been calculated. Since the energy potential of water heated by the earth's core is its heat output, the heat output formula has been used (2). The energy potential has been calculated for three temperature scenarios. Table 4 shows that as the geothermal water temperature rises, the energy potential and annual amount of thermal energy increase. Due to the large range of processed data, the evaluation of the energy potential by the authors in a conservative scenario of the implementation of a geothermal well with a water temperature of $65^{\circ} \mathrm{C}$ is given in Table 5 .

Table 5. Evaluation of the energy potential of a geothermal well in a conservative scenario with a water temperature of $65^{\circ} \mathrm{C}$.

\begin{tabular}{lc}
\hline \multicolumn{1}{c}{ Geothermal Water Temperature $\left({ }^{\circ} \mathbf{C}\right)$} & 65 \\
\hline $\begin{array}{l}\text { Amount of heat produced annually from } \\
\text { geothermal energy for DH (MWh) }\end{array}$ & 7939.75 \\
$\begin{array}{l}\text { Amount of heat produced annually from } \\
\text { geothermal energy for DHW (MWh) }\end{array}$ & 4275.25 \\
Total amount of annual heat produced from \\
geothermal energy (MWh)
\end{tabular}

The results of Tables 4 and 5 clearly show how the energy potential and the annual amount of thermal energy increase with increasing geothermal water temperature. Using data from the technical study of the geothermal well, the energy balance of the geothermal source GTK-1 was calculated for three temperature scenarios (pessimistic, conservative, and optimistic) of geothermal water.

\subsection{Assessment of the Economic Feasibility of Using GE and the Payback Period of the Implemented Project}

The assessment of economic profitability was recalculated by calculating the net present value, and the return-on-investment method was used. We considered two variants - a pessimistic and an optimistic scenario.

In the calculations, we considered the following input data:

1. Quantity delivered to GE per year;

2. Credit financing up to $90 \%$ of the realized investment;

3. Interest rate- $-0.75 \%$;

4. Loan maturity-12 years;

5. Annual increase in operating costs-by $1 \%$ per year;

6. Discount rate- $7.5 \%$.

In Table 6 , the recalculation of the evaluation of the economic efficiency of the implemented geothermal project for the pessimistic scenario is shown.

Based on the economic assessment, and assuming Tables 6 and 7 have the considered inputs, we came to the following partial conclusions:

- $\quad$ The project would achieve a return of 16.4 years in a pessimistic scenario.

- The project would achieve a negative cash flow in the years 2022 to 2025 until, in 2026, the cash flow would reach a positive value, which would increase in subsequent years.

- $\quad$ The project would achieve a return of 7.4 years in an optimistic scenario.

- In an optimistic scenario, the project would achieve a high positive cash flow from the beginning, which would increase in subsequent years. 
Table 6. Calculation of the evaluation of the economic efficiency of the implemented geothermal project for the pessimistic scenario.

\section{Pessimistic Scenario}

\begin{tabular}{|c|c|c|c|c|c|c|c|c|c|c|c|}
\hline & Pessimistic Scenario & & & & & & & & & & \\
\hline 1. & Total Investment Costs (EUR) & \multicolumn{10}{|c|}{$2,459,687$} \\
\hline 2. & Credit Share of Total Investment & \multicolumn{10}{|c|}{$90 \%$} \\
\hline 3. & Credit Amount (EUR) & \multicolumn{10}{|c|}{$2,213,718$} \\
\hline 4. & Interest Rate & \multicolumn{10}{|c|}{$0.75 \%$} \\
\hline 5. & Credit Payment Period (Years) & \multicolumn{10}{|c|}{12} \\
\hline 6. & Annual Operating Costs (EUR) & \multicolumn{10}{|c|}{29,129} \\
\hline 7. & Annual Savings on NG (EUR) & \multicolumn{10}{|c|}{228,843} \\
\hline 8. & Discount Rate & \multicolumn{10}{|c|}{$7.5 \%$} \\
\hline 9. & Year & 2022 & 2023 & 2024 & 2025 & 2026 & 2027 & 2028 & 2029 & & 2031 \\
\hline 10. & Number of Year & 1 & 2 & 3 & 4 & 5 & 6 & 7 & 8 & 9 & 10 \\
\hline 11. & Year Annual Sales/Operating CF (EUR) & 228,843 & 228,843 & 228,843 & 228,843 & 228,843 & 228,843 & 228,843 & 228,843 & 228,843 & 228,843 \\
\hline 12. & Annual Increase in Operating Costs & - & $1 \%$ & $1 \%$ & $1 \%$ & $1 \%$ & $1 \%$ & $1 \%$ & $1 \%$ & $1 \%$ & $1 \%$ \\
\hline 13. & Operating Costs (EUR) & 29,129 & 29,421 & 29,715 & 30,012 & 30,312 & 30,615 & 30,921 & 31,231 & 31,543 & 31,858 \\
\hline 14. & Annual Depreciation (EUR) & 187,252 & 187,252 & 187,252 & 187,252 & 187,252 & 187,252 & 128,745 & 128,745 & 90,307 & 90,307 \\
\hline 15. & Credit Repayment (EUR) & 184,477 & 184,477 & 184,477 & 184,477 & 184,477 & 184,477 & 184,477 & 184,477 & 184,477 & 184,477 \\
\hline 16. & Credit Balance (EUR) & $2,213,718$ & $2,029,242$ & $1,844,765$ & $1,660,289$ & $1,475,812$ & $1,291,336$ & $1,106,859$ & 922,383 & 737,906 & 553,430 \\
\hline 17. & Annual Interest on the Credit (EUR) & 16,603 & 15,219 & 13,836 & 12,452 & 11,069 & 9685 & 8301 & 6918 & 5534 & 4151 \\
\hline 18. & CF $($ EUR $)$ & -4141 & -3049 & -1960 & -873 & 210 & 1291 & 60,876 & 61,950 & 101,459 & 102,527 \\
\hline 21. & NPV (EUR) & $-247,239$ & $-247,475$ & $-246,818$ & $-245,393$ & $-243,341$ & $-240,865$ & $-244,736$ & $-247,849$ & $-254,102$ & $-259,498$ \\
\hline 22. & Payback Period (Years) & \multicolumn{10}{|c|}{16.4} \\
\hline
\end{tabular}


Table 7. Calculation of the evaluation of the economic efficiency of the implemented geothermal project for the optimistic scenario.

\begin{tabular}{|c|c|c|c|c|c|c|c|c|c|c|c|}
\hline & Optimistic Scenario & & & & & & & & & & \\
\hline 1. & Total Investment Costs (EUR) & \multicolumn{10}{|c|}{$2,459,687$} \\
\hline 2. & Credit Share of Total Investment & \multicolumn{10}{|c|}{$90 \%$} \\
\hline 3. & Credit Amount (EUR) & \multicolumn{10}{|c|}{$2,213,718$} \\
\hline 4. & Interest Rate & \multicolumn{10}{|c|}{$0.75 \%$} \\
\hline 5. & Credit Payment Period (Years) & \multicolumn{10}{|c|}{12} \\
\hline 6. & Annual Operating Costs (EUR) & \multicolumn{10}{|c|}{29,129} \\
\hline 7. & Annual Savings on NG (EUR) & \multicolumn{10}{|c|}{283,420} \\
\hline 8. & Discount Rate & \multicolumn{10}{|c|}{$7.5 \%$} \\
\hline 9. & Year & 2022 & 2023 & 2024 & 2025 & 2026 & 2027 & 2028 & 2029 & 2030 & 2031 \\
\hline 10. & Number of Year & 1 & 2 & 3 & 4 & 5 & 6 & 7 & 8 & 9 & 10 \\
\hline 11. & Year Annual Sales/Operating CF (EUR) & 283,420 & 283,420 & 283,420 & 283,420 & 283,420 & 283,420 & 283,420 & 283,420 & 283,420 & 283,420 \\
\hline 12. & Annual Increase Operating Costs & - & $1 \%$ & $1 \%$ & $1 \%$ & $1 \%$ & $1 \%$ & $1 \%$ & $1 \%$ & $1 \%$ & $1 \%$ \\
\hline 13. & Operating Costs (EUR) & 29,129 & 29,421 & 29,715 & 30,012 & 30,312 & 30,615 & 30,921 & 31,231 & 31,543 & 31,858 \\
\hline 14. & Annual Depreciation (EUR) & 187,252 & 187,252 & 187,252 & 187,252 & 187,252 & 187,252 & 128,745 & 128,745 & 90,307 & 90,307 \\
\hline 15. & Credit Repayment (EUR) & 184,477 & 184,477 & 184,477 & 184,477 & 184,477 & 184,477 & 184,477 & 184,477 & 184,477 & 184,477 \\
\hline 16. & Credit Balance (EUR) & $2,213,718$ & $2,029,242$ & $1,844,765$ & $1,660,289$ & $1,475,812$ & $1,291,336$ & $1,106,859$ & 922,383 & 737,906 & 553,430 \\
\hline 17. & Annual Interest on the Credit (EUR) & 16,603 & 15,219 & 13,836 & 12,452 & 11,069 & 9685 & 8301 & 6918 & 5534 & 4151 \\
\hline 18. & CF (EUR) & 50,436 & 51,528 & 52,617 & 53,704 & 54,787 & 55,868 & 115,453 & 116,527 & 156,036 & 157,104 \\
\hline 21. & NPV (EUR) & $-205,384$ & $-166,865$ & $-130,323$ & $-95,672$ & $-62,827$ & $-31,706$ & -8931 & 12,743 & 29,548 & 45,601 \\
\hline 22. & Payback Period (Years) & \multicolumn{10}{|c|}{7.4} \\
\hline
\end{tabular}


The payback period of the project in the optimistic scenario is very attractive and is advantageous for the specified parameters. A higher share of credit financing has a significant effect on the payback period.

The presented data create a synergy for the final conclusion that the implementation of this project will be an effective investment in the future.

\section{Conclusions}

Geothermal wells offer a number of positive options for reducing negative environmental impacts in the long term. In theory, the projected energy potential of the well would be able to supply the modeled housing estate with warm water intended for heating and the preparation of hot service water. One of the most burdensome aspects of today's society is energy. In particular, energy in households, especially heating and cooling, contributes significantly to negative impacts on the country as a whole. In the case of Slovakia, there is currently a system of supported RES and limited use of fossil resources. In the case of the specific location of the Podtatranska Basin, we propose to use the potential of geothermal energy for heating domestic housing units (housing estates). This will help to limit the combustion of natural gas and, in the long term, save money on the purchase of NG and achieve increased energy security and stability. The use of geothermal energy for housing estate heating will bring a number of benefits to this area. GE can also be used in a combined way (heating and electricity production) for greenhouse heating for growing crops and flowers, for fish farming, etc. Primarily, it will offer an ecological benefit in the form of significant emission reductions in the combustion of processes $\left(\mathrm{NOx}, \mathrm{SO}_{2}, \mathrm{CO}, \mathrm{TZL}\right)$. Currently, the city's thermal economy burns natural gas and coal. Geothermal energy is a highly ecological source; immediately after heating use, it will be drained off to a nearby surface stream. Another benefit will be that it will reduce dependence on the imports of primary heat sources (NG and coal) and replace them with a renewable energy source. Finally, the use of geothermal energy will lead to a lower heating bill for the inhabitants of the housing estate.

Currently, the aim is to use RES technology that contributes as much as possible to reducing the negative consequences of energy use on the global climate system. The topic is vital, according to current developments in energy policy in the EU and around the world. At the end of October 2021, the UN World Climate Summit was held in Glasgow; it highlighted the need to address the issue of reducing emissions in energy production. Our contribution, in terms of the use of geothermal energy, highlights a clean renewable resource and is therefore highly relevant for future generations.

Author Contributions: Conceptualization: A.S. and E.S.; methodology: A.S. and E.S.; software: G.W. and J.R.; validation: A.S. and E.S.; formal analysis: A.S. and E.S.; investigation and resources: A.S. and G.W.; data curation: A.S. and E.S.; writing-original draft preparation: J.R. and G.W.; writing-review and editing: A.S. and E.S.; visualization: A.S. and E.S.; supervision: A.S. and E.S.; project administration and funding acquisition: G.W. and J.R. All authors have read and agreed to the published version of the manuscript.

Funding: This research received no external funding.

Institutional Review Board Statement: Not applicable.

Informed Consent Statement: Not applicable.

Data Availability Statement: Data sharing is not applicable to this article.

Acknowledgments: This work is supported by the Scientific Grant Agency of the Ministry of Education, Science, Research, and Sport of the Slovak Republic, project KEGA 048TUKE-4/2021, Universal educational-competitive platform.

Conflicts of Interest: The authors declare no conflict of interest. 


\section{References}

1. IPCC. 2018: Global Warming of $1.5^{\circ} \mathrm{C}$. An IPCC Special Report on the Impacts of Global Warming of $1.5^{\circ} \mathrm{C}$ above Pre-Industrial Levels and Related Global Greenhouse Gas Emission Pathways, in the Context of Strengthening the Global Response to the Threat of Climate Change, Sustainable Development, and Efforts to Eradicate Poverty. Masson-Delmotte, V., Zhai, P., Pörtner, H.-O., Roberts, D., Skea, J., Shukla, P.R., Pirani, A., Moufouma-Okia, W., Péan, C., Pidcock, R., et al., Eds.; Available online: https://www.ipcc.ch/site/ assets/uploads/sites/2/2019/06/SR15_Full_Report_High_Res.pdf (accessed on 15 September 2021).

2. Braunmiller, G.; Horbaj, P.; Jasminská, N. Geothermal energy and power generation in Germany. Communications 2009, 11, 64-66.

3. Rybár, R.; Kudelas, D.; Beer, M. Selected problems of classification of energy sources—What are renewable energy sources? Acta Montan. Slovaca 2015, 20, 172-180.

4. Eurostat. Renewable Energy Statistics. 2020. Available online: https:/ / ec.europa.eu/eurostat/statistics-explained/index.php/ Renewable_energy_statistics (accessed on 10 September 2021).

5. Sowizdzal, A. Geothermal Energy Resources in Poland-Overview of the Current State of Knowledge. Renew. Sustain. Energy Rev. 2018, 82, 4020-4027. [CrossRef]

6. Wilberforcea, T.; Baroutajib, A.; ElHassana, Z.; Thompsona, J.; Soudane, B.; Olab, A.G. Prospects and challenges of concentrated solar photovoltaics andenhanced geothermal energy technologies. Sci. Total Environ. 2019, 659, 851-861. [CrossRef] [PubMed]

7. Sliwa, T.; Sapinska-Sliwa, A.; Gonet, A.; Kowalski, T.; Sojczynska, A. Geothermal Boreholes in Poland-Overview of the Current State of Knowledge. Energies 2021, 14, 3251. [CrossRef]

8. Koščo, J.; Tauš, P.; Taušová, M.; Jeňo, M. Geothermal energy-One of the resources of tourism expansion in Slovakia. Acta Montan. Slovaca 2016, 21, 171-179.

9. Barbier, E. Geothermal energy technology and current status: An overview. Renew. Sustain. Energy Rev. 2002, 6, 3-65. [CrossRef]

10. Hudeček, V.; Zapletal, P.; Stoniš, M.; Sojka, R. Results from dealing with rock and gas outburst prevention in the Czech Republic. Arch. Min. Sci. 2013, 58, 779-787.

11. Borovič, S.; Markovič, I. Utilization and tourism valorisation of geothermal waters in Croatia. Renew. Sustain. Energy Rev. 2015, 44, 52-63. [CrossRef]

12. Cehlár, M.; Jurkasová, Z.; Kudelas, D.; Tutko, R.; Mendel, J. Geothermal Power Plant in Conditions of Geological and Hydrological Characteristics. Adv. Mater. Res. 2014, 1001, 63-74. [CrossRef]

13. Ferenc, Š. Geotermálna Energia a jej Využitie, 1st ed.; Belanium Univerzity Mateja Bela v Banskej Bystrici: Banská Bystrica, Slovakia, 2015; p. 154.

14. STATISTA. Historical Carbon Dioxide Emissions from Global Fossil Fuel Combustion and Industrial Processes from 1758 to 2020. 2020. Available online: https://www.statista.com/statistics/264699/worldwide-co2-emissions/ (accessed on 25 September 2021).

15. Rybár, P. Zdroje geotermálnej energie a možnosti ich využívania. Acta Montan. Slovaca 2010, 12, 31-41. Available online: https:/ / core.ac.uk/download/pdf/25941789.pdf (accessed on 25 September 2021).

16. Tometz, L.; Dugáček, D. Potenciál podzemných vôd Slovenska ako obnovitel'ných zdrojov energie. Acta Montan. Slovaca 2010, 15, 116-125. Available online: https:// core.ac.uk/download/pdf/25955231.pdf (accessed on 15 September 2021).

17. Barbacki, A.; Miecznik, M.; Tomaszewska, B.; Skrzypczak, R. Assessment of the Lower Carboniferous-Devonian Aquifer as a Source of Geothermal Energy in the Silesian-Kraków Region (Poland). Energies 2020, 13, 6694. [CrossRef]

18. Fendek, M.; Hanzel, V.; Bodiš, D.; Nemčok, J. Hydrotermálne Pomery Popradskej Kotliny. Manuskript.Archív Tatra Thermálu, a.s.; Archív Tatra Thermál a.s. Poprad: Poprad, Slovakia, 1992; p. 99.

19. Franko, O.; Remšík, A.; Fendek, M. a kol. Atlas Geotermálnej Energie Slovenska, Bratislava: Štátny Geologický Ústav Dionýza Štúra. 2010. Available online: http:/ / apl.geology.sk/atlasge (accessed on 3 January 2022).

20. Slovenská Agentúra Životného Prostredia. Kjótsky Protokol k Rámcovému Dohovoru OSN o Zmene Klímy. Available online: https:/ / www.enviroportal.sk/dokumenty/medzinarodne-dohovory/dohovor/2 (accessed on 25 September 2021).

21. Enviroportál MŽP SR. Available online: file:///C:/Users/Erika/AppData/Local/Temp/soh_geotermalny_vrt_kezmarok_ optimised_asice_soh_geotermalny_vrt_kezmarok_optimised_redigovane-.pdf (accessed on 3 January 2022).

22. Rybár, P.; Drebenstedt, C.; Cehlár, M.; Domaracká, L.; Khouri, S.; Dietze, T. Mining Investment; Vydavatelství a nakladatelství Aleš Čeněk: Plzeň, Czech Republic, 2019; 250p.

23. Kvantifikácia Emisií: Metodický Postup Pre Tvorbu Regionálnych Nízkouhlíkových Stratégií, Priatelia Zeme-CEPA. 2020. Available online: https:/ / cepa.priateliazeme.sk/images/publikacie/EVS_vystupy/M10_web.pdf (accessed on 28 September 2021).

24. Zloženie Zemného Plynu, Spal'ovacie Teplo a Výhrevnost', Emisný Factor. Available online: https://www.spp.sk/sk/velkizakaznici/zemny-plyn/o-zemnom-plyne/emisie/ (accessed on 30 September 2021).

25. zlRESnie-zemneho-plynu-a-emisny-faktor. Available online: https://www.spp-distribucia.sk/dodavatelia/informacie/zlRESniezemneho-plynu-a-emisny-faktor/ (accessed on 30 September 2021).

26. Všeobecné Emisné Závislosti a Všeobecné Emisné Factory. Available online: https://www.minzp.sk/ovzdusie/ochranaovzdusia/zdroje-znecistovania-ovzdusia/novy-adresar/vseobecne-emisne-zavislosti-vseobecne-emisne-faktory.html (accessed on 30 September 2021).

27. Specific Heat Formula. Available online: https://www.toppr.com/guides/physics-formulas/specific-heat-formula/ (accessed on 3 January 2022). 